\title{
REVIEW OF THE GENUS GENNAEUS
}

\author{
BY C. WILLIAIM BEEBE, \\ Curator of Birds.
}

\section{PART I.}

Evolution as a phenomenon is beyond dispute. The exact methods of evolution are only partly clear. We have so far failed to discern many of the ways and means by which the organisms of our day have acquired their adaptations, have differentiated their tissues, or have survived the competition of past generations. One thing is certain: no single theory will suffice to account for the evolution of life in general, nor even for a single organ of any individual. If careful study of the subject has taught us nothing else, it has constrained us to believe in multiple causes; in an eternal plexus of actions and reactions. And it is as impossible to believe that any one character subserves only a single function throughout the life of an individual, as that its inception in past time-whether gradual or sudden-and its development, was brought about solely by the action of any isolated factor.

I wish that every worker along the lines of evolutionary research would pin to his desk, place in his watch or strive always to keep vividly in both conscious and subconscious thought some such symbol of the eternal interaction of factors as Prof. Henry F. Osborn has given us. ${ }^{1}$

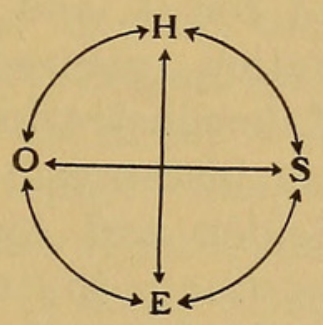

Heredity

Ontogeny

Environment

Selection

With such a "wheel of life," both controlling and stimulating, there would be less swinging of the pendulum to extremes, p. 298 .

${ }^{1}$ Science. XXVII. 1908 , p. 14 ; and Jour. Acad. Nat. Sci. Phila. XV. 1912, 
less striving to make every fact, every color, every hybrid, every tropism, fit some pet theory. There would be less arbitrary refutation, more leniency in perceiving the modicum of truth which may lie at the bottom of the most unpromising theory. This is the principal thought which the study of the family of pheasants has aroused; the realization of the plexus of factors dominating or indirectly affecting the evolution of the race and the development of the individual.

\section{PART II.}

The name Euplocomus was established by Temminck eightyfour years ago (1830), and has been expanded and maintained by many excellent authorities since that date. Today it is generally admitted to be a compound group and has been divided into as many as five genera. These are Gennaeus, Hierophasis, Diardigallus, Lophura and Acomus. Any careful study of the comparative claims of this quintet to full recognition, emphasizes most profoundly the wholly artificial character of any linear classification, and although the discussion of this is not the main thesis of the paper, yet it is interesting to consider it briefly; especially as I wish to illustrate the thought presented in Part I.

In recent years there has been a redundancy of discussion as to whether species owe more to continuous or to discontinuous variation, a better term for the latter being saltation. For several reasons I purposely avoid using the term mutation in this brief paper. When I began my studies of the pheasants I was consciously or subconsciously prejudiced against the "mutation theory," chiefly perhaps because it appeared that altogether too much was claimed for it, and if the most convincing proof of any given mutation required several generations, there was slight chance of demonstrating it among birds save in a few isolated, favorable instances. But the more I observed such species as the Golden and Amherst Pheasants (Chrysolophus pictus and amherstiae), the color relations in both sexes, and the results of hybridism, the more necessary some such phenomenon as saltation appeared to be, in these particular instances. That saltations occur in this family I consider satisfactorily proved by the Black-throated Golden 
Pheasant and the Black-shouldered Peafowl. I am now of the opinion that both forms of variation have been operative in the origin of wild forms and that the difference between them is pronounced if not profound. As an example of continuous variation I would cite the entire genus Phasianus (as I have recently restricted that group ${ }^{1}$ ). The supergenus Euplocamus well illustrates in its generic divisions what seem to be saltations.

The moment one attempts to define genera and subgenera in such a homogeneous group of organisms as the pheasants, one becomes aware of the personal equation. In the division into subfamilies I have sought to eliminate this by making use of the only consistent character which I could discover, namely, the sequence of moult of the tail feathers. With the impossibility of appeal to osteological or other fundamental characters, we are compelled to fall back upon purely superficial distinctions. Where the resemblances are as numerous as the differences, and yet when convenience in discussing the various groups demands some taxonomic isolation, however artificial, one again instinctively begins a search for something which will help to eliminate the personal element. This personal equation is in very truth affected by $\mathrm{H}$ and $\mathrm{O}$ and $\mathrm{E}$ and $\mathrm{S}$, and its variation is enormous. So it behooves one to attempt to base one's taxonomic belief on something more stable and more acceptable to foreign fellow ornithologists, than the mere credo derived from the multitudinous mental forces, both true and erroneous, resulting from American education and American environment.

Looking over the groups of pheasants, in number about a score, it seems to me that there is a criterion which may be adopted for differentiation into genera. Like the sequence of tail moult it is a character which must be consistently applied throughout the family, and, also like that character, it is abstractly doubtless of no value, at least in many other families of birds. But if it helps in deciding a few cases which seem so evenly balanced that their position might rest upon the turn of a coin, it will be worth while. This factor which throughout my studies has gained in cumulative significance, is that, no two species of any one genus occupy the same geographic area. This 
is true of so many groups that with the removal of reevesi and soemmerringii from Phasianus it holds good throughout the pheasants. And now in considering the status of the euplocamine pheasants, we are able, by applying it, to make our division rest on something beside wholly tentative and altogether artificial separations.

For in this case we are dealing with generic relationships of so subtle and complex a nature that a satisfactory decision on mere color and pattern and crest characters seems impossible. By invoking unlimited additional taxonomic castes or by employing a classification imagined in the three planes of space, the whole matter is at once simplified. For example, few would object to this scheme:

Subfamily Phasianinae.

Supergenus Euplocamus.

Genus Gennaeus.

Subgenus Hierophasis.

Then again an additional division, called perhaps Section, should be instituted to include the Fire-backed Pheasants, Diardigallus, Lophura and Acomus, occupying a distinct niche between the subfamily and supergenus. And so on.

The fineness of the distinction is well shown by the following groupings:

Classification by

Fiery back $\left\{\begin{array}{l}\text { Gennaeus + Hierophasis } \\ \text { Diardigallus + Lophura + Acomus }\end{array}\right.$

Number
of rectrices $\left\{\begin{array}{l}\text { Gennaeus }+ \text { Hierophasis }+ \text { Diardigallus } \\ \text { Acomus }\end{array}\right.$

Color of facial $\left\{\begin{array}{l}\text { Gennaeus }+ \text { Hierophasis }+ \text { Diardigallus } \\ \text { Lophura }+ \text { Acomus }\end{array}\right.$

Taking into consideration the distributional factor, we find (as in the utilization of the tail-moult character) that one of 
the most generally accepted classifications remains undisturbed. My new point of view merely provides a more logical, consistent basis. With its accompanying rough summary of geographic distribution, I suggest the following:

Genus Gennaeus Himalayan Terai, Assam, Burma, South China, Formosa, Annam, Hainan.

Subgenera Gennaeus

Hierophasis

Genus Lophura Siam, Malay Peninsula, Sumatra, Borneo. Subgenera Diardigallus

\section{Lophurá}

Genus Acomus South Malay Peninsula, Sumatra, Borneo.

If edwardsi proves to occupy the same territory in general with some more typical Gennaeus, I should at once remove it, together with its close relation swinhoii, and give Hierophasis full generic recognition. This has as many characters to warrant it as militate against it. The final settlement of its position should always be consistent with the chief use of taxonomy; clarity of relationship combined with the greatest use to the widest circle of workers.

The two points which I wish to emphasize are, first, the existence of two distinct types of specific relation in the family of Pheasants; and second, the possible correlation of generic distinction with geographic isolation.

\section{PART III.}

For many reasons the genus Gennaeus is the most interesting in the family Phasianidae, and especially because of the puzzling nature of many of the forms. The birds of this group are commonly called Kaleege and Silver Pheasants. It will result in least confusion and comply with the custom of more ornithologists if the former be used as a common generic term.

In the field, my experience with these birds extends from the haunts of albocristatus in Kashmir to nycthemerus in Fok- 
ien, and from horsfieldi in Upper Burma to lineatus in Lower Burma. I collected or made notes upon many of the forms, not only of adults in full plumage but of moulting birds and those in immature dress. Forearmed with the details of what had already been published on the subject, I was able to search more intelligently and with more direct design than would otherwise have been the case. More than this, however, was the aid given by the English sportsmen in Burma, who in some cases furnished me with data and specimens which were of the greatest help. In several instances these were the very men who had collected the original types, so their assistance cannot be overestimated.

In the study of museum specimens I was not so fortunate. The Indian Museum in Calcutta was open to me and there I found and studied a very good collection, including the types of andersoni, melanonotus and several other unique pheasants. The museums of Paris and Berlin also possess interesting specimens but Oates' collection of Gennaeus at the British Museum with over one hundred and sixty specimens and at least fourteen types was not available for study in the summer of 1912 . Now that two years have passed and no report has been made upon this collection I offer a preliminary summary of my study of this group, depending upon Oates' published descriptions of his supposed species. I am quite sure that any future investigations of the British Museum collection will in no way affect the general results I have reached.

I feel all the more certain in stating this belief because I find myself in almost perfect agreement with Prof. Allessandro Ghigi. It is most significant that while the conclusions of this Italian ornithologist were reached by a study of the phenomena of experimental hybridism and mine by independent observation of wild shot individuals, our results differ only in very minor details. His paper to which I refer is Ricerche di Sistematica Sperimentale sul genere Gennaeus Wagler ${ }^{1}$, forming the most thorough and masterly contribution to the subject which has yet appeared. Owing to the excellent keys and descriptions which he presents, I omit their duplication in this paper, giving only my general studies and results.

${ }_{1}$ Memoria R. Accademia delle Scienze dell' Istituto di Bologna, 1909. 
The tangle which has arisen about this genus centers in Burma, and, in a word, the whole question resolves itself into whether the numerous forms which have been described from that country are valid species and subspecies or only hybrids, the naming of which might be continued indefinitely without benefit to the understanding of the genus.

In order even to begin to clear up the problem it is necessary to have a definite starting point and for this I have chosen the Lineated Kaleege (G. lineatus). Geographically and pigmentally this species occupies a central position. From the point of view of color and pattern it is the most generalized of all the species, while its uniformity over almost its entire range leaves no doubt as to its right to true specific recognition. The black and white on the upper plumage is broken up into fine vermiculation, the two being about equal in extent, the very specialized color extremes of solid white or black being thus lacking. A further hint of its more generalized type is the superficial resemblance which it bears to the nearly related tropical genera, Acomus and Diardigallus.

From this point even a superficial survey of the genus shows two, and very probably three main lines of divergence. To the north and westward along the Himalayan terai extends a succession of dark feathered birds, in which the whites are reduced or concentrated on certain limited portions of the plumage. From east to west these are horsfieldi, melanonotus, leucomelanus and albocristatus. In all four there is a small amount of variation, but, inter se, no actual crossing has ever been recorded in a wild state, nor did most careful search and inquiry on my part reveal a single instance. I have taken this up in detail in my monograph and there is no need to reproduce it here.

It is important to note that the distinctions between the four Himalayan Kaleege Pheasants have been shown by Ghigi to behave in experimental crossing exactly as though they had been derived by mutation, not blending as do the characters of the Burmese birds.

To the northeast of lineatus we find a second line of Gennaeus Pheasants, of which the most widely distributed is nycthe- 
merus, the Silver Kaleege. On the island of Hainan is an offshoot from this, whiteheadi, quite close to the typical species, but of course worthy of specific recognition on account of its complete geographic isolation.

A third line, quite distinct from lineatus, is found to the southeast in Annam. This is edwardsi whose connection with iineatus at least as a direct offshoot is at present somewhat obscure. Although it is known only from a few specimens from Annam, yet its rather close relationship with swinhoii is of great interest. The latter inhabits the island of Formosa, and with its tropical, Lophura-like brilliance of color differs much from nycthemerus, the only species at present inhabiting southeast China. Edwardsi, however, shows a very probable linking relationship, less specialized, and much nearer the supposed center or origin.

After carefully going over all the data available, I cannot see that there are any other species worthy of recognition on grounds similar to the nine Kaleege I have mentioned.

Centering our attention again on Burma and the adjacent Chinese states, we find that most of the country is occupied by three species, lineatus, horsfieldi and nycthemerus. Now in all the genera of pheasants there is, as far as I know, no case of two congeneric species occupying the same territory. This was not true as long as reevesi and soemmerringii were included in Phasianus, a very obviously erroneous association, which I have attempted to better. We find that in addition to the nine Gennaeus I have already mentioned, there have been described under binomial names, no fewer than twenty-six forms. Almost without exception these are all found within the range of one or the other of the three above mentioned, widely-distributed species, and not only this but they occur along the borders where the three approach one another. After studying these forms from every point of view possible, there is no doubt whatever in my mind but that all are feral hybrids. In some way after the three main types of Kaleege became differentiated, they approached one another again, working along the narrow, intersecting valleys of Central and Upper Burma, where cross-breeding took place, apparently as freely as it does in captivity. The 
English ornithologist, Mr. Eugene W. Oates, toward the end of his life, became interested in these Burmese Kaleege and gathered all the specimens possible. He had no belief in the hybridizing of these birds, and so strong was this attitude, that the naming of new forms became an obsession with him. $\mathrm{He}$ grew intolerant of criticism and welcomed neither argument nor proof, however convincing, that any of his species were other than normally evolved forms. But aside from this, his work was sincere, and however limited his ability to view the subject from more than one angle, he at least labored to gather together a splendid collection, and we are greatly indebted to him for giving this unusual phenomenon such prominence.

Of the twenty-six so-called species, Oates is responsible for nineteen, a goodly percentage of which were based on single specimens.

The conclusions which Ghigi draws from his experiments seem important enough to quote in full, both the original and the translation.

"Returning to the birds forming the subject of the present study, if we proceed to examine G. leucomelanus and G. horsfieldi, or rather this last one and $G$. lineatus, we see that they differ in a complexity of characters, which, in the hybrids are so arranged as to produce an intermediate form, or else, they transmit them in a different association from that existing in the progenital species. Granted that these intermediate forms or with the characters associated in a different manner, may be constant in their descent, it is clear that two distinct species have the power to give origin to a new form by crossing.

"If, however, we consider G. leucomelanus and G. muthura or else the first and $G$. albocristatus, it is clear that from hybrids between them, we are not able to obtain new forms, as the difference consists in each case of only one pair of characters, antagonistic and unresolvable. The hybrids of the first pair will have the white fringe on the rump or will not be provided with it; those from the second pair will have the crest black or will have it white; they will belong then either to one or the other species, and even if they should be intermediate in the sense of having the white fringes not as large as in leucomelanus, or the 
crest not as light as in albocristatus, it is plain, that they cannot give origin to any new subspecies, because from what I have shown in my researches, and from what is established in the abundant hybridological literature of today, these hybrids, which differ in only two antagonistic characters, give place in successive generations to the separation of such characters according to the formula of Mendel, returning thence to the. pure progenital species."1

After finding and studying the Himalayan Kaleege, I later visited Burma and there in the south first met with lineatus. My next studies took me to Mandalay, eastward beyond Maymyo, and northward toward the Ruby Mines District and Bhamo. I then spent considerable time in the Myitkyina District far up the Irrawaddy, and among the Shan Mountains to the east and south, to beyond the Yunnan border. Here, thanks to the exact details given me by Major Nisbett, I was able to collect and observe a number of the forms at the very localities where the types were collected.

From this very limited locality six forms of Gennaeus had been recorded. Of these I found no perfectly typical specimens, but pheasants which approximated four, besides a fifth which was not supposed to occur here. In addition I collected birds, which if judged by the characters used in separating the already named forms, would supply at least four additional species.

\footnotetext{
${ }_{1}^{1}$ Riportandomi agli uccelli che formano oggetto del presente studio, se noi prendiamo ad esaminare il G. leucomelanus ed il G. horsfieldi, oppure quest'ultimo ed il $G$, lineatus rileviamo che essi differiscono per un complesso di caratteri i quali, negl'ibridi, si fondono in maniera da produrre una forma intermedia, oppure si trasmettono in associazione diversa da quella esistente nelle specie progenitrici. Dato che queste forme intermedie od a caratteri diversamente associati, siano stabili nella loro discendenza, è chiaro che a due specie distinte compete la facolta di dare origine per incrocio a nuove forme.

Se invece consideriamo il G.leucomelanos ed il G. muthura, oppure il primo ed il G. albocristatus, è chiaro che dalle unioni provocate fra di loro non si possono ottenere nuove forme, in quanto la differenza consiste per ciascun caso in una sola coppia di caratteri antagonisti ed indecomponibili. Gl'ibridi della prima coppia avranno le frange bianche sul groppone o ne saranno sprovvisti; quelli della seconda coppia avranno il ciuffo nero o lo avranno biancastro: apparterranno dunque nettamente o all'una od all'altra specie, e quand'anche essi fossero intermedi nel senso di avere le frange bianche non cosi ampie come nel leucomelanus od il ciuffo non cosi chiaro come nell'albocristatus, è evidente che essi non possono dare origine ad alcuna nuova sottospecie, perchè da quanto ho esposto nelle mie ricerche, e da quanto si rileva nella numerosa letteratura ibridologica odierna, questi ibridi i quali differiscono per due soli caratteri antagonisti, danno luogo nelle generazioni successive alla separazione di tali caratteri secondo la formula mendeliana, ritornando quindi alle specie progenitrici pure.
} 
The species supposed to inhabit this region are the following :

1. affinis (1 male from the River Namli; two thousand feet; east of Myitkyina).

2. granti (1 male from Puntum; six thousand feet; eight miles east of Sadon).

3. nisbetti (An imperfect male from Mt. Kachin; twentyfive hundred feet; fives miles east of Sadon).

4. cliffordi (The district in general).

5. batemani (The district in general).

6. horsfieldi (The district in general).

At the locality from which affinis is recorded, the lower River Namli, I found only horsfieldi, which was dominant and almost typical, and a vermiculated bird associated with it which closely resembled the description of obscurus, but differed from it as much as do the most nearly related named species. The two forms were living in close association, the first flock containing three birds, all males, two of which were horsfieldi. In fact this was about the numerical percentage of the latter in this vicinity. On two occasions I saw a distinctly lighter bird in company with horsfieldi but I failed to secure it. My next stop was at Pungatong, some twenty miles farther east, at an elevation of about four thousand feet. Here I located a flock of eleven Kaleege, or what was probably two families of four and five respectively, and two single cock birds. Each afternoon these would unite and take the same route to water, down a gently sloping hillside covered with light forest, across the trail and on down to the stream at the bottom of a rather steep ravine. I watched these birds carefully day after day until I could actually recognize the individuals, in spite of the fact that they were usually well looked after by a mob of Laughing Thrushes. Then I began shooting and secured no fewer than eight birds out of the eleven. This comprised all of one family of two parents and two almost full-grown young males in firstyear plumage; the adult male parent of the second family with a young female of the year, and both of the solitary cock birds- 
fully adult. The tale of individuals was as follows, using Oates' nomenclature:

Family number one:

I. Adult male. On the whole, this bird resembled horsfieldi, but it had the narrow rump fringe and lengthened tail of batemani, the intense blue, nonvermiculated rump of mearsi, and in addition the scarlet legs and feet of nisbetti. The central tailfeathers were sparingly but strongly vermiculated with white for most of their length, the terminal fifth being clear black.

2. Adult female. This bird which was constantly associated with the above cock, (in fact I secured both with one shot) was not distinguishable from females of horsfieldi, except for the somewhat longer tail. Wellgrown as were the two young birds, more than once I saw this female allow them to take food away from her, and from this and other actions, besides the constant association of the four birds before they joined the others for the afternoon's descent to water, there is not the slightest doubt in my mind that this was a a single family of Kaleege.

3. First-year male. Typical horsfieldi as found in Assam, with tail of normal length, but with the basal vermiculation on the inner rectrices visible for a half-inch beyond the upper tail-coverts.

4. First-year male. Between obscurus and davisoni, with characters of each form.

The two following birds I judged to be parent and young:

5. Adult male. Superficially close to lineatus with somewhat coarser vermiculations, and with the outer webs of the outer tail-feathers almost unmarked black as in andersoni.... The central tail-feathers were vermiculated throughout, with no hint of a pure white area. There was no trace of a rump fringe.

6. First-year female. This bird does not correspond to the description of the females of any form. The gen- 
eral color above was olive brown, very minutely vermiculated with black, except along the margins of the feathers, where the black dying out, the pure olive brown showed paler and clearer. The primaries were brownish black, densely mottled with grayish-brown on the outer webs. The secondaries were similar, with the color of the outer webs changing into that of the coverts and remainder of the upper plumage.

The chin and throat were white, tinged with brown along the margins. On the under parts the light color persisted as a well-defined buffy shaft-stripe. The rest of the feather was clear olive-brown, with but little mottling except on the center of the lower breast and abdomen, where the entire feather was irregularly blackened, especially along the enlarged shaft-stripe. The under tail-coverts were the blackest of all the contour feathers, most of them showing brown only along the margin. The outer and median tail-feathers were chestnut, obscurely but coarsely mottled with black. Toward the central pairs the chestnut changed to a brown, and the darker color became a coarse vermiculation, the lines irregular and lying obliquely to the shaft.

The facial skin was scarlet; the irides light hazel; legs and feet pale neutral. leaden gray.

I have gone into this in detail to show what variation I found among the females of this group of Pheasants.

7. Adult male. One of the solitary males was horsfieldi in length of tail and general markings, except that there was more vermiculation on the central tailfeathers than I have seen in any bird from Assam, and the inner wing-coverts were very strongly margined with white.

8. Adult male. The second male I shot on sight, and at such close range that I nearly blew it to pieces. At first glance it seemed to be a Silver Pheasant (nycthemerus) and stood out sharply from all its companions on both the occasions when I watched it work- 
ing down hill. The second time I had my gun and secured it at once. It proved to be a very dark representative of what has been called ripponi, but differing in having greenish, instead of scarlet legs and feet.

All this astounding variety of Kaleege I found within two miles of the dâk bungalow at Pungatong, ass()ciating together, and, as I have said, with satisfactory evidence of being in families. Even if the birds were of no immediate relationship however, the fact of their remarkable variation is none the less indicative of hybridism. This is typical of what I found to exist in other parts of Burma. The Arrakan country and Annam I did not visit and hence I cannot speak at first hand with regard to the birds which inhabit those regions.

All the specimens which I gathered in northern Burma tend to exhibit this individual variation and blending of characters, and in all my observations there is nothing to show any pronounced uniformity in the forms I have mentioned. But while thus being compelled to consider these as unworthy of specific validity, there is an interesting phase of the subject in regard to certain of the other forms. Some of these Pheasants which apparently owe their peculiar color and pattern to the crossing of two feral species, seem to have found more or less isolated regions where they have become established. They thus do not transgress the rule of each species being confined to its individual range. It would seem that a saltation of sorts must have entered into these cases, to fix the evanescent hybridic characters, but this we can at present only surmise. It is difficult to know exactly how to treat these, but inasmuch as they have usurped a comparatively large extent of country, and within its limits seem to breed fairly true, I see no reason why, tentatively at least, they should not be recognized, their mode of origin being kept always in mind. As far as I know, up to the present time, there has never been intentional recognition of wild hybrids as species, but if any of the four forms which I mention ultimately prove to breed true over a definite extent of country, 
I see no reason why we should not distinguish them by a distinct name. They would assuredly have as much right to one as Carpodacus mutans, the House Finch which was introduced less than forty years ago into the Hawaiian Islands by man, and which has received this new specific name ${ }^{1}$ because its colors are now yellow or orange instead of crimson.

These Kaleege are four in number, sharpei, ripponi, oatesi and cuvieri... The first two are perhaps most worthy of inclusion in the list of tentative hybrid species, and until we learn more of the range and variation of the remaining two, I shall give them the benefit of the doubt, and a place in this category. G. williamsi is a form quite widely distributed within the limits of horsfieldi between the Chin Mountains and the Irrawaddy, and farther to the west, but the few specimens I have seen were too variable to consider them even tentatively as other than fairly homogeneous hybrids.

I shall take up the four in order.

\section{GENNAEUS SHARPEI.}

Lineatus is found normally from sea-level up to a height of seventeen hundred and rarely two thousand feet, almost never higher, although I have one pair of these birds, almost typical, from Thandung, Toungoo, at forty-three hundred feet. Its range includes much of central Lower Burma on both banks of the Irrawaddy, as far east as $99^{\circ}$ East Longitude. Well within this area and throughout a north and south distance of more than four hundred and twenty miles, specimens of the pheasant named sharpei have been taken. Usually the points of capture have been at considerable elevations, none lower than two thousand feet and ranging upward to six thousand. So it seems that, quite within the range of one of the parent species, a subordinate form has gained a foothold and, produced by the crossing of lineatus probably with nycthemerus, has by reason of a consistantly inhabited, higher elevation, been able to establish itself, and to extend in a considerable direction north and south.

Ghigi says in regard to sharpei, the translation being given as literally as possible: "We have seen how G. sharpei differs from lineatus in the fact that the upper parts rather than

${ }^{1}$ Grinnell, The Auk, XXIX. 1912, p. 24. 
thinly and finely striped with white are over-run by a few large white-stripes; in the same manner as we have seen in the complex hybrids Nos. $47-49$, which have $1 / 2$ of lineatus, $3 / 8$ of muthura and $1 / 8$ only of nycthemerus. We might believe that in this series the character of lineatus might dominate, because represented by one-half, and because the two sexes of this species have taken part in its genealogy. We might also expect that the $3 / 8$ of muthura would dominate over the single $1 / 8$ of nycthemerus and have the effect of rendering the series darker. Instead the $1 / 8$ nycthemerus dominates in a way to cause the contraction of the bands and shows how small a quantity of blood of this last may be sufficient to originate, by crossing with lineatus, a form identical with sharpei."

\section{GENNAEUS RIPPONI.}

To this form should be joined jonesi, as the two are indistinguishable from the published descriptions. I knew that ripponi was supposed to cover considerable territory in Yunnan and the Shan country, and indeed I found the birds in western Yunnan and as I have related, a very closely pigmented individual in northeastern Burma. Not, however, until I had access to an unexpected and unusually large amount of material was its wide distribution proved beyond doubt. For a year or more a Chinaman had assiduously collected Silver Kaleege Pheasants in various parts of Yunnan and the Northern Shan States, and when he had gathered six large bales, he boxed them up, labelled them "ducks' feathers" and shipped them via Bhamo to Rangoon, en route to the milliners of Europe. But the custom officials at Rangoon, having had previous experience with Chinamen, investigated and in place of the feathers of domestic ducks, found hundreds of skins of Silver Kaleege, with a scattering of Lady Amherst and Burmese Bar-tailed Pheasants. The bales were promptly confiscated and condemned, and at the moment when awaiting destruction I was fortunate enough to come across the great mass of skins. I began at once to set official machinery in motion and with the help of a very amiable collector of Customs and Dr. Annandale of the Indian Museum, the entire lot was turned over to me. I spent considerable time studying the fragments, and later the best skins were picked out and sent to me. 
I found that about twenty-five per cent. were pure nycthemerus while sixty per cent. were equally typical ripponi, the remaining: fifteen per cent. showing intermediate grades between the two. Later I compared this great lot with several ripponi skins and found them almost identical, though fluctuating slightly in the direction of whiter nycthemerus or with the blacker shades of the so-called rufipes. With this evidence I do not hesitate to record this form as very probably hybrid in origin, but which in some way has at present become sufficiently distributed and established to warrant a sub-specific designation.

Ghigi says: "Taking G. nycthemerus as a point of departure we find among my hybrids, forms which differ from it to the same extent as G. jonesi (ripponi) and G. rufipes. The males (nychthemerus $\mathrm{x}$ muthura) $\mathrm{x}$ nycthemerus, correspond exactly in their upper parts to the first of the two species now cited."

\section{GENNAEUS CUVIERI AND OATESI.}

The status of these two forms rests upon different evidence. Both have been obtained from the region west of the range of lineatus and south of horsfieldi; cuvieri from the moutains of North Arrakan and oatesi, farther south at about $18^{\circ}$ North Latitude. About a dozen specimens of cuvieri have been taken, the first named by Temminck in 1820 , while of oatesi only two or three are known, collected since 1893. The fact that these birds occur actually beyond the range of any other species and removed from any contiguous borders of the haunts of other Kaleege, is sufficient reason at least for giving them special mention, whether or not future exploration will extend the ranges of either lineatus or horsfieldi to include the haunts of these forms. Combined with the fine vermiculation of the upper plumage of lineatus, both add the white rump fringe of horsfieldi, so that no matter what their present status, there is little doubt as to their origin. I refrain from giving them trinomials, as no actual gradation has been discovered between them and either of the other species. 
In conclusion, the Kaleege Pheasants forming the genus Gennaeus, seem to me to warrant the following disposition:

FULL SPECIES.

lineatus

horsfieldi

melanonotus

leucomelanus

albocristatus

nycthemerus nycthemerus

whiteheadi

edwardsi

swinhoii

SPECIES TENTATIVELY ADIMITTED.

sharpei

nycthemerus ripponi

cuvieri

oatesi
HYBRIDS.

affinis

andersoni

annamensis

assimilis

atlayi

batemani

beli

cliffordi

davisoni

elegans

granti

haringtoni

jonesi $=$ ripponi.

macdonaldi

mearsi

nisbetti

obscurus

ommansyi

prendergasti

rufipes

wickhami

williamsi

SUMMARY OF NAMED HYBRID GENNAEUS. affinis Oates.

Ann. Mag. Nat. His. (7) XI. 1903, p. 231.

Single male killed by Major Nisbett, river Namli, east of Myitkyina. 
andersoni Elliot.

Proc. Zool. Soc. London, 1871, p. 137.

Type in Indian Museum, Calcutta.

Several specimens; Anderson in Yunnan; Rippon at Warar Bun, 6,000 feet, in Kachin Mountains, 30 miles east of Bhamo.

annamensis Grant.

Bull. Brit. Orn. Club, XIX. 1907, p. 13.

Type in British Museum.

Three specimens; Vassal, Bali region, interior of Annam.

assimilis Oates.

Ann. Mag. Nat. His. (7) XIV. 1904, p. 286.

Types in Oates Collection, British Museum.

Six specimens, Ruby Mines District.

atlayi Oates.

Ann. Mag. Nat. His. (8) V. 1910, p. 162.

Types in Oates Collection, British Museum.

Seven specimens, Atlay, Ruby Mines District.

batemani Oates.

Journ. Bombay Nat. His. Soc. XVII. 1906, p. 11.

Types in Oates Collection, British Museum.

Eight specimens, Districts of Katha, Myitkyina and Bhamo.

beli Oustalet.

Bull. Mus. Nat. His. Paris, 1898, p. 258.

Types in Paris Museum.

Several specimens; Bel, Eastern Annam between Hué and the mountains.

cliffordi Oates.

Ann. Mag. Nat. His. (7) XIV. 1904, p. 286.

Types in Oates Collection, British Museum.

Six specimens ; Myitkyina Dist., east of Irrawaddy. 
davisoni Grant.

Cat. Birds British Museum, XXII. 1893, p. 304.

Type male in British Museum; type female in Oates Collection, British Museum.

About ten specimens, vicinity of Bhamo and in Yunnan.

elegans

Listed in Oates Collection.

granti Oates.

Ann. Mag. Nat. His. (8) V. 1910, p. 163.

Type in British Museum.

Single male; Nisbett, Puntum, east of Sadon.

haringtoni Oates.

Ann. Mag. Nat. His. (8) V. 1910, p. 162.

Types in Oates Collection, British Museum.

Single pair; Harington, Nilum Kha, Bhamo District.

jonesi Oates (=ripponi).

Ibis, 1903 , p. 97.

Types in British Museum.

Distribution same as ripponi.

macdonaldi Oates.

Journ. Bombay Nat. His. Soc. XVII. 1906, p. 10.

Type male in Oates Collection, British Museum.

Specimens from Chin Mountains, from Mt. Victoria to Fort White.

mearsi Oates.

Ann. Mag. Nat. His. (8) V. 1910, p. 164.

Type male in Oates Collection, British Museum.

Several; Mears, from Sylhet; Bateman from Kamaing, Myitkyina District; also North Khasi Hills, Manipur, Tippera, and Goalpara in Assam. 
nisbetti Oates.

Ibis, 1903 , p. 99.

Type male in British Museum.

Incomplete skin of male; Nisbett, five miles east of Sadon, 2,500 feet.

obscurus Oates.

Ann. Mag. Nat. His. (7) XIV. 1904, p. 283.

Type female in Oates Collection, British Museum.

Specimens from Katha District.

ommansyi

Listed in Oates Collection.

prendergasti Oates.

Jour. Bombay Nat. His. Soc. XVII. 1906, p. 10.

Specimens from North Arracan.

rufipes Oates.

Manual Game Birds India, Part I. 1898, p. 362.

Specimens from Ruby Mines District in the vicinity of Mogok.

wickhami Oates.

Manual Game Birds India, Part II. 1899, p. 495.

Type female in Oates Collection, British Museum.

Specimens from the Chin Mountains.

williamsi Oates.

Manual Game Birds India, Part I. 1898, p. 342.

Over thirty specimens in Oates Collection. Between Chin Mountains and the Irrawaddy. Williams, from Kalewa; others at Chindwin, near Wuntho. 


\section{$2 \mathrm{BHL}$ Biodiversity Heritage Library}

Beebe, William. 1914. "Review of the genus Gennaeus." Zoologica : scientific contributions of the New York Zoological Society 1(17), 303-323.

https://doi.org/10.5962/p.203802.

View This Item Online: $\underline{\text { https://www.biodiversitylibrary.org/item/97326 }}$

DOI: https://doi.org/10.5962/p.203802

Permalink: https://www.biodiversitylibrary.org/partpdf/203802

\section{Holding Institution}

Harvard University, Museum of Comparative Zoology, Ernst Mayr Library

\section{Sponsored by}

Harvard University, Museum of Comparative Zoology, Ernst Mayr Library

\section{Copyright \& Reuse}

Copyright Status: Public domain. The BHL considers that this work is no longer under copyright protection.

This document was created from content at the Biodiversity Heritage Library, the world's largest open access digital library for biodiversity literature and archives. Visit BHL at https://www.biodiversitylibrary.org. 